Jurnal Keperawatan Silampari

Volume 5, Nomor 1, Desember 2021

e-ISSN: 2581-1975

p-ISSN: 2597-7482

DOI: https://doi.org/10.31539/jks.v5i1.2673

\title{
PENGALAMAN IBU YANG MERAWAT REMAJA SKIZOFRENIA PASCA RAWAT INAP
}

\author{
Chatarina Suryaningsih \\ Universitas Jenderal Achmad Yani \\ chatarina.surya@yahoo.com
}

\begin{abstract}
ABSTRAK
Penelitian ini bertujuan untuk mengeksplorasi pengalaman ibu merawat remaja skizofrenia pasca rawat inap. Jenis penelitian ini adalah penelitian kualitatif dengan pendekatan fenomenologi deskriptif. Hasil penelitian ini menunjukkan bahwa partisipan yang ikut serta dalam penelitian ini terdiri dari $7 \mathrm{ibu}$ yang merawat anak remaja dengan skizofrenia, dengan rentang usia 39 tahun sampai dengan 57 tahun. Sebagian besar partisipan sebagai ibu rumah tangga dan tingkat pendidikan partisipan antara SD sampai dengan SMA. Semua partisipan mempunyai remaja skizofrenia di rumah. Tempat tinggal partisipan berada di wilayah Bandung. Simpulan, penelitian ini menghasilkan enam tema yaitu respon psikologis selama merawat anak, dukungan yang didapatkan ibu untuk melanjutkan pengobatan anak, adanya gangguan aktivitas sehari-hari, upaya pengobatan yang dilakukan ibu untuk kesembuhan anaknya, strategi koping selama merawat anak, stigma yang dirasakan ibu selama merawat anak.
\end{abstract}

Kata Kunci : Pengalaman Ibu, Remaja Skizofrenia

\section{ABSTRACT}

This study aims to explore the experience of mothers caring for schizophrenic adolescents after hospitalization. This type of research is qualitative research with a descriptive phenomenological approach. The results of this study indicate that the participants who took part in this study consisted of 7 mothers who cared for adolescent children with schizophrenia, with an age range of 39 years to 57 years. Most of the participants were housewives, and the education level of the participants was from elementary to high school. All participants had schizophrenic teenagers at home. The participant's residence is in the Bandung area. In conclusion, this study resulted in six themes, namely psychological responses during caring for children, support received by mothers to continue treatment of children, disturbances in daily activities, treatment efforts made by mothers to heal their children, coping strategies while caring for children, stigma felt by mothers during treatment. Take care of children.

Keywords: Mother's Experience, Schizophrenic Adolescents

\section{PENDAHULUAN}

Pengalaman keluarga dalam merawat anak dengan skizofrenia memiliki pengalaman yang berbeda. Merawat anak merupakan tugas ibu dalam menjalankan peran di keluarga. Peran ibu dalam keluarga, yaitu: memenuhi kebutuhan fisiologis dan psikologis anak, merawat, mengurus keluarga, mendidik, mengatur dan mengendalikan anak, memberi 
rangsangan (stimulus) dan pelajaran bagi anak. Ibu yang memiliki anak dengan skizofrenia akan mengalami hidup dibawah tekanan, hidup dengan beban emosional, melihat cahaya dalam kegelapan meskipun kesulitan (Subagyo et al., 2020; Andri et al., 2019; Suryaningsih \& Imelisa, 2018).

Pekerjaan seorang ibu secara signifikan terganggu atau terbatasi ketika anaknya didiagnosis skizofrenia. Ibu akan menghadapi pengalaman dan dampak yang buruk memiliki anak yang didiagnosis skizofrenia (Aruan \& Sari, 2018). Keluarga merupakan sumber pemberi kekuatan dan kenyamanan bagi anak skizofrenia, keluarga juga dapat memberikan dukungan berupa perawatan dan pengobatan secara alami. Perawatan yang berpusat pada keluarga (family centered care) akan memberikan pelayanan keperawatan yang berkualitas melalui hubungan terapeutik antara perawat, anak, dan keluarga (Diorarta \& Pasaribu, 2018).

Perawatan yang dilakukan oleh keluarga didasari dengan rasa penuh kasih sayang, dan adanya pendidikan tentang nilai-nilai kehidupan baik agama maupun sosial budaya yang diberikan oleh keluarga merupakan faktor yang sangat kondusif untuk mempersiapkan anak menjadi pribadi dan anggota masyarakat yang sehat (Harkomah, 2019). Merawat anak merupakan tugas ibu dalam menjalankan peran di keluarga. Peran ibu dalam keluarga, yaitu: memenuhi kebutuhan fisiologis dan psikologis anak, merawat, mengurus keluarga, mendidik, mengatur dan mengendalikan anak, memberi rangsangan (stimulus) dan pelajaran bagi anak (Mahali et al., 2019).

Pengalaman kehidupan ibu sehari-hari yang memiliki anak dewasa dengan penyakit mental jangka panjang. Penelitian ini menemukan satu utama tema: Anak dewasa yang berjuang dengan penyakit mental selalu didalam pikiran ibunya. Pengetahuan ibu dalam pengalaman hidup sehari-hari sangat penting dalam rangka mendukung anak mereka dan dengan demikian kemungkinan meningkatkan ibu-ibu ini menjadi sumber kekuatan bagi anak mereka. Ibu akan menghadapi pengalaman dan dampak yang buruk memiliki anak yang didiagnosis skizofrenia (Suryaningsih \& Imelisa, 2018).

Remaja dengan skizofrenia adalah remaja yang mengalami gangguan mental sehingga mengalami gangguan dalam menafsirkan realitas normal yang menimbulkan berbagai masalah dalam berpikir (kognitif), perilaku atau emosi (Candra \& Kartika, 2019). Pada dasarnya remaja dengan skizofrenia sama dengan skizofrenia pada orang dewasa. Skizofrenia pada remaja terjadi pada awal kehidupan dan memiliki dampak besar pada perilaku dan perkembangan anak. Skizofrenia membutuhkan pengobatan seumur hidup. Langkah untuk mengidentifikasi dan memulai pengobatan bagi penderita skizofrenia pada remaja, harus dilakukan sedini mungkin dan secara signifikan, sehingga dapat meningkatkan hasil jangka panjang pada mereka (Peristianto \& Lestari, 2018).

Masalah yang akan muncul pada masa remaja dengan skizofrenia akan menunjukkan gangguan perkembangan dan gangguan afektif yang ditandai dengan halusinasi pendengaran dan delusi. Gangguan perkembangan saraf premorbid, termasuk bahasa, motorik, dan defisit sosial lebih sering dan lebih jelas terjadi pada masa remaja yang didiagnosis skizofrenia (Peristianto \& Lestari, 2018).

Keluarga merupakan sumber pemberi kekuatan dan kenyamanan bagi anak skizofrenia, keluarga juga dapat memberikan dukungan berupa perawatan dan pengobatan secara alami. Perawatan dan pengobatan secara alami yang dilakukan keluarga dapat berupa kasih sayang untuk mencegah terjadinya kekambuhan, keluarga juga dapat memberikan empati dalam menurunkan stres anak yang menderita skizofrenia. Dalam melakukan peran tersebut, keluarga membutuhkan suatu informasi kesehatan dalam merawat remaja dengan 
skizofrenia, sehingga keluarga dapat memahami kebutuhan perawatan remaja dengan skizofrenia (Wijanarko \& Ediati, 2017).

Perawat anak dapat melakukan asuhan yang berpusat pada keluarga (family centered care) untuk memberdayakan dan memampukan keluarga yang memiliki remaja skizofrenia sehingga remaja dengan skizofrenia dapat berkembang optimal sesuai dengan perkembangannya (Suryaningsih \& Imelisa, 2018). Peneliti sebagai seorang perawat anak yang akan memberikan intervensi keperawatan dengan melibatkan ibu-ibu dalam merawat remajanya yang didiagnosis skizofrenia, merasa tertarik untuk menggali lebih jauh pengalaman ibu yang merawat remaja yang didiagnosis skizofrenia.

Penelitian mengenai skizofrenia telah banyak dilakukan, tetapi penelitian kualitatif mengenai pengalaman ibu dalam merawat remaja dengan skizofrenia masih sangat jarang dilakukan sehingga peneliti kemudian melakukan penelitian dengan melakukan wawancara mendalam secara langsung pada ibu yang merawat anak remaja dengan skizofrenia secara langsung. Penelitian ini memberikan informasi secara langsung pada ibu, dan diperoleh banyak informasi yang dapat dijadikan sebagai landasan peneliti lain untuk melakukan penelitian dengan melakukan intervensi pada keluarga dan remaja skizofrenia.

\section{METODE PENELITIAN}

Jenis penelitian yang digunakan adalah penelitian kualitatif dengan menggunakan fenomenologi deskriptif. Fenomenologi deskriptif yaitu filosofi fenomenologi yang melibatkan eksplorasi langsung, analisis dan deskripsi fenomena tertentu, bebas dari dugaan (hipotesis) dan diteliti melalui pengungkapan intuisi peneliti secara maksimal. Fenomenologi deskriptif menggali keluasaan, kekayaan, dan kedalaman pengalaman seseorang yang didasari dengan mengesampingkan sementara pengetahuan, teori dan asumsi penelitian terhadap suatu fenomena.

Teknik pengambilan sampel pada penelitian ini adalah dengan purposive sampling, yaitu suatu teknik penetapan sampel dengan cara memilih individu dan tempat untuk diteliti yang dianggap sampel tersebut dapat mewakili karakteristik fenomena dan populasi dalam riset penelitian. Jumlah sampel yang direkomendasikan untuk penelitian fenomenologi adalah 3 hingga 10 orang, Partisipan dalam penelitian ini berjumlah 7 partisipan. Pengambilan partisipan berhenti sampai terjadi saturasi data. Proses penelitian ini dilaksanakan selama 1 bulan.

Dalam penelitian kualitatif instrumen utama adalah peneliti itu sendiri, peneliti berperan sebagai instrumen dalam penelitian menggunakan metode wawancara mendalam semi terstruktur. Peneliti menggunakan alat bantu pengumpulan data untuk membantu penelitian yaitu dengan alat perekam wawancara yang menggunakan voice recorder dalam bentuk handphone. Peneliti menggunakan teknik analisis data yaitu dengan metode analisis Colaizzi (1978).

\section{HASIL PENELITIAN \\ Karakteristik Partisipan}

Sebelum dilakukan penelitian, peneliti memberikan penjelasan pada ibu yang merawat anak remaja dengan skizofrenia tentang tujuan, manfaat dan proses penelitian, kemudian memberikan lembar informed consent yang ditandatangani untuk menyatakan kesediaan menjadi partisipan dalam penelitian. Ibu yang bersedia menjadi partisipan akan memberikan persetujuan dalam lembar informed consent. Jumlah partisipan dalam penelitian ini didapatkan 7 orang ibu. 
Kriteria dipilih berdasarkan inklusi dan berdasarkan pada saturasi data, dimana saturasi data didapatkan pada partisipan ke 7. Partisipan yang ikut serta dalam penelitian ini terdiri dari $7 \mathrm{ibu}$ yang merawat anak remaja dengan skizofrenia, dengan rentang usia 39 tahun sampai dengan 57 tahun. Sebagian besar partisipan sebagai ibu rumah tangga dan tingkat pendidikan partisipan antara SD sampai dengan SMA. Semua partisipan mempunyai remaja skizofrenia di rumah. Tempat tinggal partisipan berada di wilayah Bandung. Partisipan bisa berkomunikasi dalam bahasa indonesia. Secara umum partisipan hanya memiliki satu remaja yang mengalami skizofrenia.

\section{Analisis Tema}

Analisis hasil wawancara mendalam yang dilakukan terhadap tujuh partisipan dengan menggunakan metode analisis Colaizzi (1978) menghasilkan enam tema yaitu: respon psikologis selama merawat anak, dukungan yang didapatkan ibu untuk melanjutkan pengobatan anak, adanya gangguan aktivitas sehari-hari, upaya pengobatan yang dilakukan ibu untuk kesembuhan anaknya, strategi koping selama merawat anak, stigma yang dirasakan ibu selama merawat anak.

Tema 1 respon psikologis selama merawat anak, Berikut pernyataan yang diungkapkan partisipan kedua:

“...banyak duka sih, soalnya kan sakitnya gak kayak sakit biasa jadi otomatis waktu tersita, semuanya dicurahkan buat " $S$ " gitu....Soalnya kan sakitnya seperti itu, harus apa, bener-bener ngejaganya deh.”

Sedangkan sedih yang dirasakan partisipan kelima karena melihat kondisi anaknya yang belum sembuh-sembuh seperti pernyataan berikut:

“....sedih aja kalau di rumah kalau belum sembuh mah....ngeliat anak itu sakit terus gitu jadi sedih.”

Ibu merasa sedih terhadap kondisi anaknya, ibu merasa marah terhadap kondisi anaknya. Partisipan tiga mengungkapkan marahnya karena penyakit anaknya belum sembuh, seperti berikut:

"...yah merawatnya biasa aja gitu, rutin kasih minum obat, ada perasaan kesel, ya kesel gitu....Kesal, marah karena sakitnya gak sembuh-sembuh... yah kesel juga seh, kadang jenuh ngeliatnya, disuruh ke pesanteren gak mau, kan di pesanteren banyak temen."

Hampir sama yang dirasakan partisipan empat dan lima. Partisipan empat menunjukkan perasaan marah berupa memarahin, menangis \& perasaan capek terhadap perilaku anaknya. Berikut pernyataan yang diungkapkan oleh partisipan empat:

“...melihat " $E$ " seperti itu, ya pasrah aja teh, kadang-kadang ya marah... kadangkadang saya juga ikut marah-marah sambil nangis... "E”" mama teh capek, saya bilang gitu. "E” teh gimana...Kadang-kadang kesel tapi kadang-kadang sadar."

Partisipan lima menunjukkan perasaan marahnya berupa sikap kesel dan capek terhadap perilaku anaknya yang tidak seperti anak normal biasanya. Hal ini diungkapkan sebagai berikut :

“...suka kesel kalau misalnya udah lewat batas "D”, gak normal, dikasih tau suka marah awalnya....kalau dulu mah cape kemana-mana harus dicari karena " $D$ " belum normal... capenya ya gak nurut-nurut, nguras tenaga karena kan beda ngerawat yang sakit batuk dengan yang sakit kayak gitu."

Remaja dengan skizofrenia memiliki gangguan untuk berpikir dan mengelola emosi. Partisipan yang merawat remaja dengan skizofrenia memiliki rasa kekhawatiran akan perilaku anaknya yang tidak diinginkan. Kekhwatiran ini diungkapkan oleh partisipan dua sebagai berikut: 
kalau nama orangnya lagi depresi kan, takutnya apa, hal-hal yang tidak diinginkan. Emang sempet ngedrop gitu ya sampai kayak mau putus asa. Kok sampe seperti itu kayak orang putus asa, nangis-nangis, takutnya gimana gitu. Ini kan khawatir takut nekat, ya apa ya, yang tidak diinginkan lah ya. Soalnya orang depresi, putus asa seperti itu kayaknya gitu... maklum kemarin sakit jadinya saya suka khawatir."

Tema 2 dukungan yang didapatkan ibu untuk melanjutkan pengobatan anak. Partisipan satu mengungkapkannya sebagai berikut:

"tetangga saya ada yang nyaranin suruh kesana, ke cisarua gitu.".

Partisipan satu menggambarkan dukungan lingkungan berupa saran dari tetangga untuk membawa anak ke Rumah Sakit Jiwa Cisarua. Sama dengan dukungan yang dirasakan oleh partisipan lima berupa saran untuk membawa anaknya ke rumah sakit. Partisipan lima mengungkapkannya sebagai berikut:

"Pertama datang ke RSJ malem-malem karena ada yang ngasih tau padahal sebelumnya udah datang ke orang pinter gak ada perubahan."

Dukungan lingkungan yang didapatkan partisipan kedua berupa kunjungan dari tetangga sekitar untuk menjenguk anaknya dan dukungan motivasi dari guru dan teman untuk kesembuhan anaknya. Berikut ungkapan dari partisipan dua :

"orang-orang disini sayang kan, tetangga banyak yang nengok dari mana-mana, itu kan saking sayangnya sama " $S$ " bukanya apa-apa....Kayak dari sekolah juga, gurugurunya, yah dari sekolah juga nengok, temen-temen terus gurunya kasih support aja...Kalau dikelas juga, saya bilangin dulu sih, kalau dikelas jangan sampai nyinggung "S", Alhamdulilah temen-temennya juga pada baik jadi gak sampai nyinggung perasaaanya teh."

Partispan empat mendapatkan pujian atas perjuangan yang dilakukan partisipan selama merawat anaknya. Partisipan merasa termotivasi untuk melanjutkan pengobatan anaknya. Berikut pernyataan yang diungkapkan oleh partisipan empat :

"Ketika "E” sembuh, tetangga bilangin ibu perjuangannya bagus jadi semangat, gak menyerah, jadi terus aja."

Selain mendapatkan dukungan dari lingkungan, partisipan empat mendapat dukungan dari anggota keluarga untuk membawa berobat. Dukungan dari anggota keluarga yang diterima partisipan berupa saran dan bantuan dana untuk membawa berobat ke rumah sakit. Partisipan emapt mengungkapkanya sebagai berikut:

"terus kakaknya bilang mah seh "E" waktu kejadian kecelakaan teh, terus aja bengong, jarang tidur, mah bawa berobat... Kakaknya paling gede suka nangis, suka bilang ke saya "mama seh "E" kalo mau berobat jangan telat-telat, jangan malu-malu minta uang kalau kekurangan uang berobat."

Dukungan dari petugas kesehatan pun dirasakan oleh partisipan. Partisipan mendapatkan saran dari petugas kesehatan bahwa sebelum dinyatakan sembuh oleh petugas kesehatan, sebaiknya ibu tetap membawa berobat ke rumah sakit jiwa. Berikut pernyataan yang diungkapkan patisipan satu:

"ibu mah tetap berusaha aja, tetap bawa ke dokter, dokter bilang ke ibu tetap sabar dan harus berobat sampai sembuh.

Sama dengan halnya yang didapatkan oleh partisipan lima. Partisipan lima mendapatkan dukungan dari petugas kesehatan untuk tetap sabar dan selalu rajin memberikan obat dan kontrol ke rumah sakit. Berikut pernyataan partisipan lima :

"yah dokter bilang ke ibu untuk tetap sabar,,,penyakit kayak gini bisa sembuh asal ibunya terus kontrol dan obatnya diminum. 
Tema 3 adanya gangguan aktivitas sehari-hari. Berikut pernyataan yang diungkapkan oleh partisipan dua:

“...kurang tidur, gak enak makan itu,soalnya anaknya waktu sakit, 2 hari tuh siang malam gak tidur, gak bisa tidur, diem aja, ya otomatis kita juga gak bisa tidur... kadangkadang kita juga jengkel kan, soalnya kan tidur juga gak enak, makan juga gak enak, kadang-kadang saya sampai turun berat badan samapi $3 \mathrm{~kg}$ waktu itu... ya aktivitas sehari-hari saya jadi terbengkalai dong, kan waktu itu pengen " $S$ " cepet sembuh."

Partisipan empat mengalami gangguan tidur dan makan akibat merawat anaknya. Gangguan tidur yang digambarkan partisipan berupa tidak bisa tidur karena menjaga anaknya yang tidak bisa tidur. Gangguan makan yang digambarkan partisipan berupa kurangnya nafsu makan yang mengakibatkan partisipan samapai mengalami sakit thypus. Pernyataan partisipan empat diungkapkan sebagai berikut:

"Ya waktu sakit teh, gimana gitu, tidur jarang, jarang tidur, karena "E" gak tidurtidur. Waktu "E" sakit, sampai sakit thypus ibu karena capek kali ya... waktu "E”" sakit mah, semua dicurahin ke "E" karena pengen sembuh. Ya inget waktu "E" sakit, perjuangan ibu mah teh, udah susah tidur, makan pun gak enak."

Tema 4 upaya pengobatan yang dilakukan ibu untuk kesembuhan anaknya. Hal ini seperti diungkapkan oleh partisipan empat:

"Ada yang nyuruh puasa 3 hari, puasa weton, udah aja ibu jalani", pernyataan partisipan enam: "ibu memaksakan " $N$ " untuk dinikahin Namun baru 1 tahu, " $N$ " udah diceraikan, terus kayaknya " $N$ " depresi dan marah-marah".

Dua pernyataan partisipan ini menunjukan bahwa partisipan berusaha melakukan pengobatan dengan menjalankan ritual yang dipercaya akan menyembuhkan anaknya yaitu dengan melakukan puasa dan memaksa menikahkan anaknya. Berikut pernyataan yang diungkapkan partisipan satu:

"Pengobatan itu teh apa,... apa namanya teh.... eee... altenatif. Itu seminggu sekali kontrol kesana, udah berapa bulan sering tapi yah gak ada perubahanya gitu”

Sama halnya yang dilakukan partisipan empat. Partisipan empat membawa anaknya ke pengobatan alternatif. Berikut pernyataan yang diungkapkan partisipam empat:

"Pertama saya bawa mah ke ustadz "A", dibawa ke atas ke toge gitu, ganti lagi ke Cianjur, sudah gitu teh dibawa lagi ke Muara Ciwdey, yang paling lama... ya gak ada perubahan malahan yang di muara Ciwidey tambah parah".

Partisipan lima juga membawa anaknya ke pengobtan alternatif untuk berobat dan mendapatkan informasi penyakit anaknya. Partisipan lima mengungkapkannya sebagai berikut:

"Saya berobat kemana-mana tapi gak sembuh, kayak ada saudara saya juga berobat kemana-mana tapi gak sembuh juga...saya bawa ke orang pinter yang punya kelebihan...saya nanyain "eyang ini bener gak, "D" sakit teh karena ilmunya udah tinggi”.

Tema 5 strategi koping selama merawat anak. Berikut pernyataan yang diungkapkan oleh partisipan:

"Dedek sering ke uminya kalau ada apa-apa ke uminya gitu walaupun bapaknya ada, gak ada uminya, gak pernah ngomong ke bapaknya, suruh ngambil apa-apa ke saya aja, ke uminya....apa aja sih, adeknya mau makan, mau ngambil minum padahal deket, maunya teh diambilin gitu, pokoknya mau ngambil apa-apa gitu, kalau sama saya diambilin, walaupun ngambil apa gitu." 
Partisipan dua juga selama merawat anaknya ketika sakit harus memberikan perhatian yang penuh kepada anaknya sehingga perhatian untuk anggota keluarga lain dihiraukan. Partisipan juga harus memenuhi kebutuhan makan, aktivitas, dan mandi anaknya. Partisipan mengungkapkannya sebagai berikut:

"Pokoknya mau kemana-mana saya ikutin, maunya apa diikutin, diikutin dulu maunya apa...Adeknya juga sekolah gak begitu saya perhatiin, pokoknya buat "S" semua... kalau waktu sakit, apa-apa mesti sama mamanya. Pas mau sembuh, dicoba aja mandiri, dicoba makan. "S" sok makan, ambil sendiri.. kalau mau kemana pengen dianter... kadang ke kamar mandi, "ma tungguin”.

Partisipan tiga dan lima juga selama merawat anaknya harus memanjakan anaknya untuk memenuhi kebutuhan sehari-hari. Partisipan tiga memanjakan anaknya dengan memenuhi kebutuhan personal hygiene, menemani saat mau tidur, mengantar pergi sekolah. Partisipan tiga mengungkapkannya sebagai berikut:

"Dari sini mah kalo berangkat sekolah suka pagi-pagi banget tapi kadang kalau lagi gak tenang, ya saya anter...Kadang kalo harus mandiin, kalo dia lagi ketakutan kan otomatis ditemenin berartikan dimandiin gitu...Kadangkan kalo ke kamar mandi aja takut, harus ditemenin sampe depan pintu kamar mandi, kadang tidur pengen ditemenin, "urutin ma, diurut"."

Partisipan lima memanjakan anaknya dengan memenuhi kebutuhan makan dan kebutuhan personal hygiene. Berikut pernyataan yang diungkapkan partisipan:

"Dulu mah ya apa-apa mesti sama saya kalo gak sama kakaknya, makan disuapin, mandi dimandiin, yah diperhatiin aja "D"nya."

Tema 6 stigma yang dirasakan ibu selama merawat anak. Berikut adalah pernyataan partisipan mengenai stigma dalam melakukan perawatan pada anaknya: partisipan tujuh:

"ngelantur orang banyak nonton, kadang malu rasanya lihat anak itu".

Pernyataan partisipan satu:

"Saya sedih sekali, bagaimana gitu nasib anak saya, terus orang-orang juga pada ngomong punya anak gak dididik, gak diapain, dibiarin aja ke jalan.”,

Partisipan empat:

"yang ngejek mah banyak, tetangga banyak yang ngejek".

Kondisi yang dialami oleh partisipan diatas akibat adanya asumsi dari masyarakat yang membuat keluarga menjadi tidak percaya diri dalam melakukan perawatan pada anaknya.

\section{PEMBAHASAN}

\section{Tema 1 : Respon Psikologis Selama Merawat Anak}

Keluarga yang merawat anak dengan skizofrenia akan mengalami kesedihan, distress dan kehilangan namun ibu tetap berjuang dan berkomitmen untuk membantu anaknya. Keluarga yang merawat remaja dengan gangguan mental, sering merasa tidak siap dan tidak didukung dalam menjalani peran tersebut, sehingga mengalami depresi ringan sampai berat. Ibu yang merawat anak dengan skizofrenia akan mengalami beban emosional. Pengalaman hidup sehari-hari ibu sangat penting dalam mendukung agar anak mereka menjadi sembuh dan tidak mengalami kekambuhan, dan dapat menjadikan ibu tersebut menjadi sumber kekuatan bagi anak-anak mereka (Mahali et al., 2019). 
Orang tua yang mempunyai anak dengan penyakit kronis akan mengalami perasaan berduka atau kehilangan seorang anak yang sempurna. Orang tua dapat atau tidak menerima terhadap kondisi anaknya. Respon psikologis ini terlihat akan muncul pada orang tua yang melakukan perawatan pada anak secara penuh (Peristianto \& Lestari, 2018).

Dukacita adalah respons normal terhadap setiap setiap kehilangan. Dukacita adaptif dimulai ketika seseorang merespons terhadap kesadaran tentang suatu ancaman kehilangan yang berkaitan dengan masa lalu, saat ini, dan masa yang mendatang. Respon psikologis perilaku adaptif individu membantu kemampuan seseorang untuk menghadapi stressor. Perilaku ini diarahkan pada penatalaksanaan stress dan didapatkan melalui pembelajaran dan pengalaman sejalan individu dalam mengidentifikasi perilaku yang dapat diterima. Perilaku adaptif psikologis dapat konstruktif atau destruktif. Perilaku konstruktif membantu individu menerima tantangan untuk menyelesaikan konflik. Perilaku destruktif mempengaruhi orientasi realitas, kemampuan pemecahan masalah, kemampuan untuk berfungsi (Gamayanti, 2016).

Anggapan remaja dengan skizofrenia merupakan ancaman dan tidak memiliki cara untuk mengatasinya hingga partisipan merasakan sedih yang berkepanjangan maka partisipan akan mengalami proses maladaptif. Akan tetapi jika partisipan tetap berusaha merawat anaknya dan mengatasi masalah yang dirasakan hingga partisipan menerima kondisi anaknya maka partisipan mengalami proses adaptif. Pada tahap ini perawat dapat memberikan informasi yang tepat bagi partisipan sehingga partisipan tidak mengalami sedih yang berkepanjangan namun menerima kondisi anaknya (Suryaningsih \& Imelisa, 2018).

\section{Tema 2 : Dukungan yang Didapatkan Ibu untuk Melanjutkan Pengobatan Anak}

Dukungan yang didapatkan oleh penderita skizofrenia berasal dari lingkungan, anggota keluarga, petugas kesehatan. Dukungan lingkungan yang didapatkan oleh partisipan berupa saran untuk membawa anaknya ke rumah sakit jiwa dan pujian kepada partisipan atas perjuangan yang dilakukan untuk kesembuhan anaknya. Dukungan anggota keluarga yang didapatkan oleh partisipan berupa saran untuk membawa ke rumah sakit jiwa dan memberikan dana pengobatan kepada partisipan. Dukungan petugas yang didapatkan oleh partisipan berupa saran untuk tetap berobat sampai sembuh.

Perawat sebagai petugas kesehatan dapat memberikan dukungan kepada keluarga yang memiliki anak dengan skizofrenia. Dukungan yang dapat dilakukan oleh Perawat, dapat berupa edukasi dan pemberdayaan keluarga dalam perencanaan terapi. Keluarga dapat memonitor tanda gejala anak dan perkembangan anaknya (Suryaningsih \& Imelisa, 2018).

Keluarga sangat berperan dalam merawat anak, hal ini sebagai salah satu proses pemulihan bagi anggota keluarga yang mengalami skizofrenia. Kelompok pendukung, dapat berperan dalam memberikan motivasi untuk keluraga yang merawat anak dengan skizofrenia, sehingga keluarga tersebut tetap semangat untuk merawat anaknya. Dukungan yang baik kepada Ibu sebagai caregiver, dapat membantu ibu yang mengalami beban emosional ketika merawat anaknya.

Perawatan yang dilakukan oleh keluarga didasari dengan rasa penuh kasih sayang, dan adanya pendidikan tentang nilai-nilai kehidupan baik agama maupun sosial budaya yang diberikan oleh keluarga merupakan faktor yang sangat kondusif untuk mempersiapkan anak menjadi pribadi dan anggota masyarakat yang sehat (Harkomah, 2019). Merawat anak merupakan tugas ibu dalam menjalankan peran di keluarga. Peran ibu dalam keluarga, yaitu: memenuhi kebutuhan fisiologis dan psikologis anak, merawat, mengurus keluarga, 
mendidik, mengatur dan mengendalikan anak, memberi rangsangan (stimulus) dan pelajaran bagi anak (Mahali et al., 2019).

\section{Tema 3 : Adanya Gangguan Aktivitas Sehari-Hari}

Perilaku remaja skizofrenia yang menuntut keluarga berada 24 jam berada disamping mereka memberikan efek yang negatif bagi penderita skizofrenia, yaitu mengalami gangguan aktivitas sehari-hari akibat merawat remaja dengan skizofrenia. Gangguan aktivitas sehari-hari yang berupa gangguan tidur, makan, akitivitas (Karindra, 2021).

Peran ibu akan terganggu atau terbatasi ketika harus merawat anggota keluarga dengan skizofrenia. Ibu sebagai caregiver selama merawat anak dengan skizofrenia tidak dapat memenuhi kebutuhan hidupnya sendiri karena semua perhatian diberikan ke anaknya. Ibu yang merawat anak dengan skizofrenia memerlukan bantuan untuk menggantikan perannya. Caregiver menunjukkan gangguan fisik selama merawat anak dengan skizofrenia. Gangguan fisik yang dialami caregiver yaitu kelelahan sampai sakit. Caregiver membutuhkan kesehatan selama merawat anak dengan skizofrenia. Caregiver selama merawat anak dengan skizofrenia akan mengalami gangguan kesehatan (Peristianto \& Lestari, 2018).

Ibu yang merawat remaja dengan skizofrenia akan mengalami gangguan aktivitas sehari-hari. Gangguan aktivitas sehari-hari ini karena peran partisipan menjadi lebih banyak dan tidak ada yang membantu perannya selama menjalani aktivitas sehari-hari. Seharusnya peran ibu dalam merawat anak yang sakit dapat digantikan oleh anggota keluarga yang lain. Kebutuhan untuk perawatan yang cukup bagi anggota keluarga. Keluarga yang merawat anggota keluarga dengan skizofrenia akan mengalami beban yang berat. Anggota keluarga hendaknya saling bergantian untuk merawat anggota keluarga yang menderita skizofrenia (Suryani et al., 2019).

Keluarga dengan anak penyakit kronis harus bertanggung jawab terhadap anaknya. Orang tua cenderung fokus terhadap semua tindakan perawatan untuk anaknya. Hal ini akan membuat keluarga mengalami gangguan aktivitas sehari-hari. Seluruh peran orang tua, waktu, energi, dan keuangan difokuskan untuk perawatan anaknya (Fitri \& Rahmandani, 2020). Aktivitas kehidupan sehari-hari adalah aktivitas yang biasanya dilakukan dalam sepanjang hari pada saat keadaan normal yang mencakup ambulasi, makan, berpakaian, mandi, menyikat gigi, dan berhias. Kondisi yang mengakibatkan kebutuhan untuk bantuan dalam aktivitas kehidupan sehari-hari bersifat akut, kronis, temporer, permanen, atau bersifat rehabilitatif (Harkomah, 2019).

Keluarga sebagai suatu sistem yang berinteraksi secara kontinu dengan anggota keluarga dan lingkungan sekitarnya. Perubahan dalam satu bagian sistem keluarga akan memepengaruhi semua bagian lain dalam sistem keluarga. Sistem keluarga dapat menimbulkan perubahan dan bereaksi terhadap perubahan tersebut. Saat anggota keluarga sakit maka akan terjadi perubahan peran dalam anggota keluarga tersebut. Peran anggota yang merawat anak yang sakit akan berubah dan digantikan oleh anggota keluarga lain sehingga sistem keluarga dapat berjalan dengan efektif (Pebrianti et al., 2017).

\section{Tema 4 : Upaya Pengobatan yang Dilakukan Ibu untuk Kesembuhan Anaknya}

Upaya pengobatan yang dilakukan ibu untuk kesembuhan anaknya yaitu dengan melakukan pandangan budaya dan kepercayaan masyarakat, pengobatan alternatif, pengobatan profesional. Pengobatan alternatif yang dilakukan partisipan juga belum menunjukkan perubahan yang lebih baik ke anaknya. Upaya pengobatan profesional yang dilakukan partisipan ternyata menunjukkan perubahan yang lebih baik sehingga merasa 
percaya bahwa pengobatan profesional membuat anaknya sembuh (Suryaningsih \& Imelisa, 2018).

Adanya peran yang dimainkan oleh faktor-faktor agama dalam budaya yang berbeda dalam mempengaruhi kesehatan mental. Profesional kesehatan mental mungkin tampak terganggu terhadap keyakinan dan praktik didukung dalam satu budaya agama dalam mempengaruhi diagnosis dan pengobatan Petugas kesehatan dalam mengatasi keluarga dengan skizofrenia akan menghadapi keluarga dari berbagai ras, etnik, dan latar belakang budaya. Penting sekali terjadi interaksi positif antara budaya praktisi perawatan kesehatan, budaya klien, dan budaya tatanan. Beberapa budaya meyakini bahwa skizofrenia mungkin disebabkan oleh roh jahat, kejadian di kehidupan sebelumnya, pemikiran buruk atau kutukan dari orang lain, rasisme, atau karena kehendak Tuhan (Pandjaitan \& Rahmasari, 2020).

Agama dan budaya, dapat berkontribusi dalam memberikan harapan pada keluarga yang merawat anak dengan skizofrenia dan dapat memberikan solusi terhadap nasib mereka. Petugas kesehatan, hendaknya memahami aspek spiritualitas keluarga yang anggotanya mengalami gangguan jiwa. Petugas kesehatan hendaknya bekerja sama dengan keluarga, dalam mengatasi gangguan jiwa yang dialami oleh anggota keluarga mereka (Rostina et al., 2020).

Rawat inap dapat diindikasikan untuk remaja yang mengalami skizofrenia dengan tujuan diagnostik, stabilisasi pengobatan, keamanan pasien. Rawat inap dapat menguragi stres pasien dan membantunya menyusun aktivitas harian. Rencana penanganan di rumah sakit seyogianya berorientasi ke masalah praktisi perawatan diri, kualitas hidup, pekerjaan, dan hubungan sosial (Kurniawan et al., 2021).

Keluarga harus mencari dan menemukan tempat yang tepat dan benar dalam penyembuhan anak dengan skizofrenia. Keluarga dapat membawa anak dengan skizofrenia ke tempat pengobatan profesional, psikolog, psikiater, praktik keperawatan dan klinik psikologi yang berlisesnsi. Rumah sakit dan klinik dapat bekerjasama secara profesional dalam memberikan terapi pada pasien dengan skizofrenia (Pandjaitan \& Rahmasari, 2020). Upaya pengobatan utama yang dapat dilakukan oleh ibu yang memiliki remaja skizofrenia yaitu dengan pengobatan konvensional dan memperhatikan latar belakang budaya keluarga (Rostina et al., 2020). Keperawatan peka budaya merupakan bentuk layanan keperawatan yang berorientasi pada penyesuaian dan penghargaan latar belakang budaya klien yang menerima layanan dan diberikan oleh tenaga keperawatan yang memahami berbagai budaya orang lain (Suryaningsih \& Imelisa, 2018).

\section{Tema 5 : Strategi Koping Selama Merawat Anak}

Masalah yang dihadapin keluarga selama merawat anaknya menuntut partisipan untuk mencari cara untuk mengatasinya sebagai mekanisme koping yang dilakukan partisipan. Strategi koping yang dilakukan keluarga bersifat positif dan negatif. Starategi koping positif yang dilakukan ibu yaitu berhati-hati dalam berbicara dengan anaknya, bersikap sabar, memberikan perhatian, mengajak anak berdoa, melakukan pengawasan pemberian obat (Candra \& Kartika, 2019).

keluarga bereaksi terhadap stressor dan menjelaskan faktor-faktor yang meningkatkan adaptasi keluarga terhadap peristiwa tersebut. Pada saat keluarga mengalami terlalu banyak stressor yang harus diatasi secara adekuat maka terjadi krisis. Dalam beradaptasi pada keadaan tersebut, dibutuhkan suatu perubahan struktur dan/atau interaksi keluarga (Menaldi \& Dewi, 2019). 
Dalam menghadapi anggota yang mengalami penyakit kronis, keluarga akan mengalami proses adaptif dan maladaptif. Hal ini tergantung dari bagaimana keluarga mengatasi permasalahan yang dihadapi sebagai mekanisme koping yang dilakukan keluraga. Koping negatif yang dilakukan keluarga yaitu menyangkal terhadap kondisi anak, menolak memberitahu atau membicarakan anaknya kepada siapa pun. Koping positif yang dilakukan keluarga yaitu melakukan penyesuain terhadap kondisi anaknya (Mahmudah \& Fitriani, 2021).

Mekanisme koping dapat berorientasi pada tugas yang mencakup penggunaan teknik pemecahan masalah secara langsung untuk menghadapi ancaman, atau dapat dengan cara mekanisme pertahanan ego. Perilaku berorientasi tugas mencakup pengunaan kemampuan kognitif untuk mengurangi stress, memecahkan masalah, menyelesaikan konflik. Mekanisme pertahanan ego adalah metode koping terhadap stres secara tidak langsung. Mekanisme pertahanan ego bertujuan untuk mengatur distress emosional dan memberikan perlindungan individu terhadap ansietas dan stres. Namun mekanisme pertahanan ego dapat menyimpang dan tidak lagi membantu seseorang dalam mengadaptasi stressor (Kitu et al., 2019).

Cara ibu berbicara dengan anaknya yang menderita skizofrenia. Ibu dapat berbicara dengan anaknya sesuai dengan budaya yang dianut dalam keluarga. Intervensi yang berpusat pada keluarga dapat meningkatkan pemahaman keluarga sebagai pemberi perawatan. Keluarga sebagai pemberi perawatan harus memahami kondisi anak yang mengalami skizofrenia. Keluarga dapat ikut berperan dalam pemberi perawatan dengan pasien skizofrenia dengan cara memberikan pengawasan terhadap kepatuhan minum obat. Pasien yang patuh minum obat dapat mengurangi efek kekambuhan pada skizofrenia (Pandjaitan \& Rahmasari, 2020).

Koping positif yang dapat dilakukan keluarga yaitu dengan mencari informasi, menyesuaikan diri dengan sesuai kondisi anaknya, memberikan perhatian, memberikan motivasi, mengajak anak untuk mendekatkan diri kepada Tuhan. Tindakan yang dapat dilakukan keluarga untuk mengatasi masalah yang dihadapi yaitu memahami kondisi yang dihadapi, menemani dan mengajak berbicara, memfasilitasi kebutuhan-kebutuhan dasar, saling memberikan dukungan dan semangat (Gamayanti, 2016).

\section{Tema 6 : Stigma yang Dirasakan Ibu Selama Merawat Anak}

Remaja dengan skizofrenia masih banyak dipandang negatif oleh masyarakat. Masyarakat yang memandang negatif terhadap penyakit ini menjadikan stigma bagi keluarga selama merawat anaknya. Adapun stigma yang dirasakan partisipan yaitu mendapat ejekan dari tetangga dan merasa malu terhadap kondisi anaknya. Keluarga yang memiliki remaja dengan skizofrenia mendapat ejekan dari tetangga karena perilaku anaknya. Perilaku anak partisipan yang tidak wajar berupa marah-marah, teriak-teriak menimbulkan rasa malu yang dirasakan keluarga (Candra \& Kartika, 2019).

Keluarga akan merasakan aib ketika memiliki anggota keluarga yang menderita skizofrenia. Aib yang dirasakan keluarga ini akan menyebabkan isolasi sosial di masyarakat. Keluarga akan memberikan perlakuan terhadap anggota keluarga yang menderita skizofrenia dengan menyembunyikan dan mengucilkan, hal ini dilakukan agar masyarakat tidak mengetahui kondisi anggota keluarga yang mengalami skizofrenia. Tindakan yang dilakukan keluarga ini, akan berpengaruh terhadap kondisi penderita skizofrenia sehingga menjadi semakin berat, dan beban yang dirasakan oleh keluarga juga akan semakin berat (Berliana \& Wardani, 2018). 
Keterbatasan dalam pergaulan di masyarakat membuat penderita skizofrenia sulit untuk sembuh. Keterbatasan pergaulan ini, dikarenakan adanya stigma yang melekat di masyarakat. Stigma yang melekat sebagai "orang gila" akan terus diingat oleh masyarakat, dan ini menjadikan faktor penderita skizofrenia sulit untuk beradaptasi dengan lingkungan. Masyarakat umum kebanyakan merasa takut, menjauhi, dan tidak mau bergaul dengan penderita skizofrenia (Malfasari et al., 2020).

Terdapat keluarga yang mempunyai persepsi negatif terhadap penederita skizofrenia. Keluarga juga mempunyai persepsi yang kurang mendukung terhadap, pengertian, dan perawatan pada skizofrenia. Masyarakat Indonesia masih beranggapan bahwa skizofrenia merupakan aib bagi keluarga, sehingga masyarakat banyak memberikan stigma terhadap keluarga yang mempunyai anak dengan skizofrenia. Masyarakat harus memberikan dukungan yang positif terhadap keluarga. Petugas kesehatan hendaknya memberikan pengetahuan dan meluruskan stigma yang terjadi di masyarakat. Keluarga seharusnya mendapatkan informasi bahwa penderita skizofrenia bisa menunjukkan perubahan yang lebih baik sehingga, keluarga tidak mengucilkan anaknya yang menderita skizofrenia (Zuraida, 2017). Seharusnya masyarakat jangan memberikan stigma pada penderita skizofrenia. Peran penyuluh sosial dapat memberikan informasi bahwa penderita skizofrenia dapat sembuh jika kontrol secara rutin dan masyarakat tidak mengucilkan penderita skizofrenia. Penyuluh sosial sangat berperan pentin dalam meluruskan stigma yang beredar di masyarakat (Peristianto \& Lestari, 2018).

\section{SIMPULAN}

Berdasarkan hasil penelitian, maka dapat disimpulkan bahwa, didapatkan 6 pokok tema, yaitu: 1) Respon psikologis selama merawat anak; 2) dukungan yang didapatkan ibu untuk melanjutkan pengobatan anak; 3) adanya gangguan aktivitas sehari-hari; 4) Upaya pengobatan yang dilakukan ibu untuk kesembuhan anaknya; 5) Strategi koping selama merawat anak; 6) Stigma yang dirasakan ibu selama merawat anak.

\section{SARAN}

Saran yang dapat diberikan oleh peneliti terhadap pihak-pihak yang terkait dalam perawatan remaja dengan skizofrenia yaitu: bagi praktisi Keperawatan Anak yaitu: hasil penelitian ini diharapkan dapat dijadikan acuan bagi perawat dalam memberikan asuhan keperawatan pada remaja skizofrenia. Perawat diharapkan dapat melakukan pengabdian kepada masyarakat mengenai stigma terhadap penderita skizofrenia sehingga penderita skizofrenia tidak dianggap aib oleh masyarakat.

Bagi peneliti Ilmu Keperawatan yaitu hasil penelitian ini mengungkap stigma yang dirasakan ibu memilki remaja skizofrenia. Penelitian keperawatan dapat dikembangkan oleh peneliti selanjutnya mengenai upaya mengatasi stigma dengan penelitian kuantitatif yaitu pengaruh pendidikan kesehatan terhadap stigma masyarakat tentang skizofrenia.

\section{DAFTAR PUSTAKA}

Andri, J., Febriawati, H., Panzilion, P., Sari, S. N \& Utama, D. A. (2019). Implementasi Keperawatan dengan Pengendalian Diri Klien Halusinasi. 1(2), 146-155. https://doi.org/https://doi.org/10.31539/jka.v1i2.922

Aruan, T. N. R., \& Sari, S. P. (2018). Gambaran Beban Ibu Sebagai Caregiver Anak dengan Skizofrenia di Poliklinik Rawat Jalan Rumah Sakit Jiwa. Jurnal Jurusan Keperawatan, $1-8$. http://eprints.undip.ac.id/63015/1/ARTIKEL_ILMIAH_TIODORA_NAOMI.pdf 
Berliana, B., \& Wardani, I. Y. (2018). Stres dan Strategi Koping Anak Jalanan di Kota Depok. Jurnal Persatuan Perawat Nasional Indonesia (JPPNI), 2(2), 108. https://doi.org/10.32419/jppni.v2i2.88

Candra, L. I. A. W., \& Kartika, H. Y. (2019). Proses Penerimaan Anggota Keluarga Orang dengan Skizofrenia. Jurnal Psikologi Udayana, 89-102. https://ojs.unud.ac.id/index.php/psikologi/article/view/47153

Diorarta, R., \& Pasaribu, J. (2018). Pengalaman Keluarga Merawat Penderita Skizofrenia dengan Masalah Utama Perilaku Kekerasan. Jurnal Keperawatan, 10(2), 106-113. http://journal.stikeskendal.ac.id/index.php/Keperawatan/article/view/319

Fitri, A., \& Rahmandani, A. (2020). Pengalaman Keterlibatan Ayah dalam Merawat Anak dengan Skizofrenia: Interpretative Phenomenological Analysis. Jurnal Empati, 9(3), 204-211. https://ejournal3.undip.ac.id/index.php/empati/article/view/28343

Gamayanti, W. (2016). Gambaran Penerimaan Diri (Self-Acceptance) pada Orang yang Mengalami Skizofrenia. Psympathic: Jurnal Ilmiah Psikologi, 3(1), 139-152. https://doi.org/10.15575/psy.v3i1.1100

Harkomah, I. (2019). Analisis Pengalaman Keluarga Merawat Pasien Skizofrenia dengan Masalah Halusinasi Pendengaran Pasca Hospitalisasi. Jurnal Endurance, 4(2), 282. https://doi.org/10.22216/jen.v4i2.3844

Karindra, A. P. (2021). Peningkatan Penerimaan Diri Pasien Skizofrenia melalui Rational Emotif Behavior Therapy. Procedia : Studi Kasus dan Intervensi Psikologi, 9(2), 7682. https://doi.org/10.22219/procedia.v9i2.16298

Kitu, I. F. M., Dwidiyanti, M., \& Wijayanti, D. Y. (2019). Terapi Keperawatan terhadap Koping Keluarga Pasien Skizofrenia. Jurnal Keperawatan Jiwa, 7(3), 253. https://doi.org/10.26714/jkj.7.3.2019.253-256

Kurniawan, R. A., Suryani, S., Hernawaty, T., \& Al-Kofahy, L. (2021). The Structure, Process, and Outcome of Mentorship on Survivor with Schizophrenia: A Case Study. Jurnal Keperawatan Padjadjaran, 9(1), 71. https://doi.org/10.24198/jkp.v9i1.1645

Mahali, F., Priyono, D., \& Budiharto, I. (2019). Eksplorasi Pengalaman Keluarga dalam Perawatan Pasien Skizofrenia di Kalimantan Barat. Tanjungpura Journal of Nursing Practice and Education, 1(1), 1-17. DOI: 10.26418/tjnpe.v1i1.35013

Mahmudah, U., \& Fitriani, D. R. (2021). Hubungan Stigma dengan Mekanisme Koping Keluarga dalam Menghadapi Pasien Agresif. Borneo Student Research (BSR), 2(2), 941-949. https://journals.umkt.ac.id/index.php/bsr/article/download/1570/786

Malfasari, E., Febtrina, R., Maulinda, D., \& Amimi, R. (2020). Analisis Tanda dan Gejala Resiko Perilaku Kekerasan pada Pasien Skizofrenia. Jurnal Ilmu Keperawatan Jiwa, 3(1), 65. https://doi.org/10.32584/jikj.v3i1.478

Menaldi, A., \& Dewi, H. C. (2019). Kelompok Dukungan untuk Caregiver Orang dengan Skizofrenia. Jurnal Psikologi, 18(1), 13. https://doi.org/10.14710/jp.18.1.13-28

Pandjaitan, E. A. A., \& Rahmasari, D. (2020). Resiliensi Pada Caregiver Penderita Skizofrenia. Jurnal Penelitian Psikologi, 07(03), 116-166. https://ejournal.unesa.ac.id/index.php/character/article/view/36327/32297

Pebrianti, S., Wijayanti, R., \& Munjiati, M. (2017). Hubungan Tipe Pola Asuh Keluarga dengan Kejadian Skizofrenia di Ruang Sakura RSUD Banyumas. The Soedirman Journal, 2(1), 17-23

Peristianto, S. V., \& Lestari, S. (2018). Peningkatan Dukungan Sosial Orang Tua dengan Anak Skizofrenia melalui Solution Focused Therapy. Jurnal Psikologi, 45(1), 15-26. https://doi.org/10.22146/jpsi.18114 
Rostina, R., Adamy, A., Abdullah, A., \& Chairurrijal, C. (2020). Perilaku dan Hambatan Pengobatan Keluarga Penderita Skizofrenia. Jurnal Ilmu Keperawatan, 8(1), 66-75. http://jurnal.unsyiah.ac.id/JIK/article/view/18003

Subagyo, W., Wahyuningsih, D., \& Mukhadiono, M. (2020). Peningkatan Kemampuan Ketrampilan Sosial Pasien Gangguan Jiwa di Masyarakat dengan Terapi Hortikultura. Jurnal Keperawatan Tilampari, 4(1), https://doi.org/https://doi.org/10.31539/jks.v4i1.1300

Suryani, S., Ningsih, E. W., \& Nuraeni, A. (2019). Knowledge, Perception, and Burden of Family in Treating Patients With Schizophrenia Who Experience Relapse. Belitung Nursing Journal, 5(4), 162-168. https://doi.org/10.33546/bnj.683

Suryaningsih, C., \& Imelisa, R. (2018). Pengalaman Psikologis Ibu dalam Merawat Remaja Skizofrenia. Prosiding Pertemuan Ilmiah Nasional Penelitian \& Pengabdian Masyarakat (PINLITAMAS 1), 1(1), 238-242. https://repository2.stikesayani.ac.id/index.php/pinlitamas1/article/view/334/291

Wijanarko, A., \& Ediati, A. (2017). Penerimaan Diri pada Orangtua yang Memiliki Anak Skizofrenia. Empati, 5(3), 424-429. https://ejournal3.undip.ac.id/index.php/empati/article/view/15362

Zuraida, Z. (2017). Konsep Diri Penderita Skizofrenia Setelah Rehabilitasi. Kognisi Jurnal, $1(2)$, 110-124. http://e-journal.potensiutama.ac.id/ojs/index.php/KOGNISI/article/view/413 